NBER WORKING PAPER SERIES

THE CONTINENTAL DOLLAR:

WHAT HAPPENED TO IT AFTER 1779?

Farley Grubb

Working Paper 13770

http://www.nber.org/papers/w13770

\author{
NATIONAL BUREAU OF ECONOMIC RESEARCH \\ 1050 Massachusetts Avenue \\ Cambridge, MA 02138 \\ February 2008
}

\begin{abstract}
A preliminary version was presented at SUNY-Binghamton and at the 2008 American Economic Association meeting in New Orleans. The author thanks the participants at these presentations and Christopher Hanes and Peter Rousseau for helpful comments. He also thanks Kelly Lynn Perkins, Nathan Richwine, and Zachary Rose for research assistance and Tracy McQueen for editorial assistance. The views expressed herein are those of the author(s) and do not necessarily reflect the views of the National Bureau of Economic Research.
\end{abstract}

NBER working papers are circulated for discussion and comment purposes. They have not been peerreviewed or been subject to the review by the NBER Board of Directors that accompanies official NBER publications.

(C) 2008 by Farley Grubb. All rights reserved. Short sections of text, not to exceed two paragraphs, may be quoted without explicit permission provided that full credit, including $\odot$ notice, is given to the source. 
The Continental Dollar: What Happened to It after 1779?

Farley Grubb

NBER Working Paper No. 13770

February 2008

JEL No. N1,N11,N2,N21

\title{
ABSTRACT
}

Congress financed the American Revolution by issuing paper Continental Dollars. The story of the Continental Dollar is familiar to all -- a lot were issued and hyper-inflation ensued. Emissions were permanently discontinued in 1779 . Thereafter, they became worthless and were forgotten. They had no impact on subsequent public finance. The veracity of the last part of this story is challenged here. Evidence is presented to establish that the disposition of the Continental Dollar remained an open question well into the 1790s. Evidence is also presented to establish the exact time path of the retirement of Continental Dollars between 1779 and 1790.

\author{
Farley Grubb \\ University of Delaware \\ Economics Department \\ Newark, DE 19716 \\ and NBER \\ grubbf@lerner.udel.edu
}




\section{The Continental Dollar: What Happened to It after 1779?*}

Congress financed the American Revolution by issuing paper Continental Dollars. The story of the Continental Dollar is familiar to all - a lot were issued and hyper-inflation ensued. Emissions were permanently discontinued in 1779. Thereafter, they became worthless and were forgotten. They had no impact on subsequent public finance. The veracity of the last part of this story is challenged here. Evidence is presented to establish that the disposition of the Continental Dollar remained an open question well into the 1790s. Evidence is also presented to establish the exact time path of the retirement of Continental Dollars between 1779 and 1790.

From 1775 through 1779 the U.S. Congress financed the American Revolution by issuing fiat paper money - the Continental Dollar. The basic story of the Continental Dollar is familiar to all. A lot were issued and hyper-inflation ensued. In 1779 Congress permanently discontinued emissions and shortly thereafter abandoned paper money. In 1781 Continental Dollars ceased to circulate as a currency and markets for Continental Dollars soon disappeared. "Not worth a Continental" became a common derogatory phrase. Being worthless, they were trashed and forgotten, producing no appreciable impact on subsequent public finance decisions. ${ }^{1}$

The post-1779 portion of this story, however, is not well documented and its veracity is challenged here. A substantial body of heretofore ignored evidence is marshaled to show that the disposition of the Continental Dollar both within Congress and among the public remained an open, controversial, and unresolved question well into the 1790s. This uncertainty affected the public's decision to hold Continental Dollars as a speculative investment compared with trashing them, trading them in the marketplace, or remitting them for taxes. This evidence is also used to document the exact amount and time path of Continental Dollars remitted to the U.S. Treasury to be burned between 1779 and 1790. A complete quantitative assessment of remittances has never been done before. It reveals ongoing activity regarding the Continental Dollar throughout the 1780s and establishes the size of the Continental Dollar debt facing the Federal Government during this period. This debt is used to explain how the Federal Government's ability to 
restructure its finances was constrained. For over a decade after 1779 the Continental Dollar continued to be an important presence in shaping the emerging U.S. financial revolution.

\section{Emission and Remittance of Continental Dollars, 1775-1790: The Quantitative Evidence}

The time path of Continental Dollars emitted by Congress and still outstanding — net of those remitted to the U.S. Treasury—is presented in Figure 1. Emissions began in June of 1775 and ended in November of 1779. Regarding net new emissions, $\$ 199,990,000$ were emitted over this period. All were still outstanding as of mid-1780. Regarding gross emissions or total printings of Continental Dollars, Congress printed an additional $\$ 41,510,000$ to be swapped onefor-one with already emitted Continental Dollars - replacing existing Continental Dollars that were either too torn or ragged to continue in circulation or were under threat of being counterfeited. Most of this currency swap took place between 1779 and 1781. Adding the $\$ 41,510,000$ issued for currency exchange to the $\$ 199,990,000$ net new emissions yields $\$ 241,500,000$ gross emissions or total printings of Continental Dollars (Grubb, 2007b, 2008). Separating gross from net emissions is important for interpreting the evidence on remittances.

[Place Figure 1 Here]

Taxes to pull Continental Dollars out of circulation were not initiated until after $1779 .^{2}$ Before 1789, under the Articles of Confederation, Congress did not have the power to directly tax the public and so could not directly redeem Continental Dollars from the public. Congress therefore asked the states to accept Continental Dollars in payment of state taxes and then remit them to Congress as part of the funding requisitions each state owed Congress. The states, however, failed to provide the funds requested before 1780. In the fall of 1779 Congress permanently discontinued emissions of Continental Dollars. On 28 June 1781 the Secretary of Congress, Charles Thomson, restated the funding-requisition quotas each state owed Congress 
with regard to remitting Continental Dollars. He indicated that $\$ 195$ million Continental Dollars were still outstanding at that time. ${ }^{3}$ These assigned quotas are listed in Table 1.

[Place Table 1 Here]

With the requisition act of 18 March 1780, Congress attempted to induce states to make specie payments to Congress as part of their funding quotas and to reduce the quantity of paper money outstanding from \$200 million Continental Dollars to \$10 million "Continental-State" Dollars. Congress gave states a discount when requisitions were paid in specie (one Spanish silver dollar being accepted in lieu of 40 Continental Dollars) and would allow states to issue one Continental-State Dollar on their own account for every 20 Continental Dollars they remitted to the U.S. Treasury to be burned. Under this scheme states removed between $\$ 31.8$ and $\$ 41.4$ million Continental Dollars from the public and remitted them to the U.S. Treasury between late 1780 and late 1781 . This experiment collapsed by late spring of 1781 and was never revived. ${ }^{4}$

As the Continental-State Dollar experiment collapsed, Continental Dollars ceased to circulate as currency (Grubb, 2007b). Being near worthless and given that organized markets for trading in Continental Dollars soon disappeared, many have assumed that the remaining Continental Dollars were simply trashed at this time, e.g. Breck (1843, pp. 15-16) concluded:

Two hundred million lost all value, and were laid aside. The annihilation was so complete that barber-shops were papered, in jest, with the bills; and the sailors, on returning from their cruise, being paid off in bundles of this worthless money, had suits of clothes made of it, and with characteristic light-heartedness turned their loss into a frolic by parading through the streets in decayed finery...

Similarly, Phillips (1866, p. 185) related the following story from a Tory newspaper in New York, the Rivington's Gazette, written on 12 May 1781:

The congress is finally bankrupt! Last Saturday a large body of inhabitants with paper dollars in their hats by way of cockades, paraded the streets of Philadelphia, carrying colors flying, with a dog tarred, and instead of the usual appendage and ornament of feathers, his back was covered with the congress' paper dollar. ... was 
directly followed by the jailor, who refused accepting the bills in purchase of a glass of rum, and afterwards by the traders of the city, who shut up their shops declining to sell any more goods but for gold and silver.

In another state, Ferguson (1961, p. 66) and Phillips (1866, p. 185) related that:

...the continental money was buried with honors. Its remains, deposited in elegant coffins, were followed to the grave by a numerous concourse; an eloquent oration was delivered narrating its services, as those of a former friend and benefactor. When the obsequies were concluded, the orator, holding to view a specimen of a new emission authorized by the state to replace the old continental, exclaimed "be thou also ready; for thou shalt surely die!" - a prophecy soon fulfilled.

But were such stories just minor political theater and Tory propaganda representing trivial amounts of Continental Dollars, or were they indicative of some mass orgy of destruction? The evidence below suggests that it was trivial. ${ }^{5}$

The total amount of Continental Dollars taxed out of circulation or otherwise removed from the public by the states, remitted to the U.S. Treasury, and burned between 1779 and 1790 is seldom discussed nor has the exact time series of outstanding balances of Continental Dollars still at large after 1779 been tallied previously in the literature. Yet the existence of three separate reports allows for the construction of such a series from direct evidence. On 14 January 1786 Joseph Nourse, the Registrar of the Treasury from 1781 to 1829 , reported to Congress the amount of Continental Dollars - face value - paid into the U.S. Treasury from May 1779 through 1785 by month, year, and source (JCC, v. 30, pp. 22-25).

In May of 1782, Michael Hillegas, Continental Treasurer under the administration of Robert Morris, reported to state Governors a portion of the report given by Nourse to Congress in 1786-the portion covering from 25 November 1780 through 23 February 1782 (Ferguson, et al., 1980, v. 5, p. 139). Hillegas' report is basically identical to Nourse's report for the period that the two overlap except that Hillegas identifies which of the remittances were just currency swaps, i.e. those affecting gross but not net emissions (Grubb, 2007b, 2008). 
Finally, on 11 May 1790 Alexander Hamilton, Secretary of the Treasury, reported to Congress the amount of Continental Dollars — face value - paid into the U.S. Treasury from November 1780 through March 1789 by day, month, year, and state. ${ }^{6}$ With the exception of a few minor omissions and discrepancies (noted below), the three reports are basically the same for the periods when they overlap. This cross-corroboration gives confidence to the numbers reported by each series when they do not overlap.

These series, slightly rearranged (put into chronological order), are reproduced in Table 2. The Hillegas report, being redundant, is not listed separately. ${ }^{7}$ Combining the three series gives a continuous quantitative monthly series from May 1779 through March 1789 of the amounts of Continental Dollars - face value — remitted by each state to the U.S. Treasury. Eliminating the overlap or duplication between the series, yields a total of $\$ 153.5$ million Continental Dollars — face value — remitted to the U.S. Treasury and burned by 1790 . Interpreting this number, however, requires additional scrutiny.

[Place Table 2 Here]

The Hillegas report identifies the purpose of each remittance, something not done in the Nourse and Hamilton reports. In particular, Hillegas identifies which remittances from the 20 May 1777 and 11 April 1778 emissions were being swapped dollar-for-dollar for the emission of 14 January 1779 (Grubb, 2007b, 2008). Comparing the entries in the Hillegas report with those in the Nourse and Hamilton reports for the period when the three reports overlap indicates that the Nourse report includes the remittance of Continental Dollars that were merely part of this currency swap, whereas the Hamilton report deliberately excludes these remittances, see Table 2. As such, the Nourse and Hillegas reports are counting remittances in reference to gross emissions or total printings of Continental Dollars $(\$ 241,500,000)$ whereas the Hamilton report 
is counting remittances in reference to net emissions $(\$ 199,990,000) .^{8}$

By inference, the numbers in the Nourse report for the period before Hamilton's report commences must represent only remittances that were part of the currency swap and so are not a reduction in net emissions. Whereas, the numbers in the Hamilton report must represent only the remittances that were part of the quota of payments each state owed Congress, i.e. reductions in net emissions outstanding. Figure 1 uses this interpretation of remittances.

This interpretation of how to count remittances is also consistent with the timing of congressional legislation. The period over which bills from the 20 May 1777 and 11 April 1778 emissions could be exchanged for bills of the 14 January 1779 emission ran from the spring of 1779 through 1 January 1781 . While most of the currency swap took place before that deadline, some of the exchanged bills continued to trickle into the U.S. Treasury through 1781 . The total sums that were eligible for exchange were $\$ 41.5$ million (Grubb, 2007b, 2008). Nourse's remittances through 1 January 1781 total \$34.4 million and through April of 1781 total \$39.9 million. The closeness of these totals, given that Nourse admits that his numbers are neither comprehensive nor complete, is further indication that Nourse's numbers, at least into late-1780, include mostly the return of old Continental bills that were being swapped for new Continental bills and not a reduction in the net amount of Continental Dollars emitted.

With the requisition act of 18 March 1780, states began to call in through taxes or other means Continental Dollars in order to issue their own individual Continental-State currency. Remittances of Continental Dollars under this scheme would not begin to roll into the U.S. Treasury until later that year, which would be consistent with the commencement date of the Hamilton report. This was a short-lived experiment ending by mid-1781 with a total of $\$ 31.8$ to \$41.4 million Continental Dollars called in through this mechanism (Grubb, 2007b). Hamilton’s 
total, starting in November of 1780, reaches these amounts by August and November 1781, respectively_about when the experiment ended, see Table $2 .{ }^{9}$

The other sums remitted after 1781 were part of the ongoing requisitions paid by the states to Congress under the 40 to 1 credit of Continental Dollars to specie dollars set by Congress in March of 1780. Interestingly, both Nourse and Hamilton indicate that no Continental Dollars were remitted to the U.S. Treasury between late 1783 and mid-1786. Apparently, once the Revolution was over and independence was officially recognized with the Treaty of Paris, states saw no need to keep remitting Continental Dollars to Congress. Only when it became clear that there would be a reckoning of accounts between the states and the Federal Government, did remittances of Continental Dollars pick up again — presumably as states positioned themselves for credits with the Federal Government. ${ }^{10}$

By 1790 the total amount of Continental Dollars (face value) still outstanding was $\$ 80.5$ million ( $\$ 200$ million of net new emission minus $\$ 119.5$ million remitted through 1789 as reported by Hamilton) or $\$ 88$ million ( $\$ 241.5$ million of gross emissions minus $\$ 153.5$ million of gross remittances as the result of combining the Hamilton and Nourse reports), see Table 2. Because Nourse admitted that his numbers were neither comprehensive nor complete, the $\$ 80.5$ million will be taken as the better estimate.

Thus by 1790, 11 years after ceasing to issue Continental Dollars and seven years after the end of the Revolution, Congress had managed to get the states to redeem in some manner and remove from the public roughly 60 percent of the net new Continental Dollars ever emitted (\$119.5 million / \$200 million). By any measure, this was quite an accomplishment—a success seldom noted in the literature-especially considering that 1785 through 1788 were depression years for the U.S. economy and that Congress' original legislation did not require redemption of 
Continental Dollars before 1797 for those issued in 1779 (Grubb, 2007b; Holton, 2007).

The $\$ 80.5$ million Continental Dollars estimated above that were still outstanding and unredeemed in 1790 is consistent with and corroborated by other evidence. It is close to Congress' guess of $\$ 78$ to $\$ 80$ million still unredeemed and unfunded as of 1791 , and it is close to Hamilton's implied estimate for $1789 .{ }^{11}$ Congress' guess of how many Continental Dollars were exchanged for bonds at the 100 to 1 default rate set by the August 1790 Funding Act (discussed below) was $\$ 6$ million, leaving $\$ 72$ to $\$ 74$ million (face value) as a total loss, i.e. never funded or redeemed. ${ }^{12}$

Figure 2 combines the information in Table 1 and the Hamilton evidence in Table 2 to chart the progress of each state in filling its quota of remittances of Continental Dollars. Delaware was the first to completely fill its quota, doing so with a single payment on 7 January 1782. Massachusetts and New Hampshire also quickly filled their quotas, completing their payments by late September 1782. After that only Rhode Island, with a single payment on 13 August 1787 , completed its quota. ${ }^{13}$ Pennsylvania reached 90 percent of its quota by 1783 , and New York reached 80 percent in 1786. New Jersey reached just over 50 percent by 1783 but made little progress thereafter. The other states, with the exception of South Carolina and Georgia who recorded no remittances in the 1780s, made slow and intermittent progress but never reached over 50 percent of their assigned quotas. No state is recorded as remitting more than its assigned quota of Continental Dollars. This fact will be used below to help explain why some people held onto Continental Dollars as a speculative investment rather than using them to pay state taxes or trading them in the marketplace during this period.

[Place Figure 2 Here]

Congress adopted the new U.S. Constitution in 1789 and under its auspices restructured 
its finances with the Funding Act of 4 August 1790. The act increased the default rate to 100 Continental Dollars being exchangeable for 1 dollar in Federal Government interest-bearing bonds. It also, for the first time, made the default on the Continental Dollar irrevocably permanent. The bonds were callable perpetuities that paid 6 percent annual interest, but with onethird paying no interest until 1800 . Only $\$ 6$ million, of the $\$ 80.5$ million, Continental Dollars still outstanding in 1790 were so exchanged between 1791 and 1797—when the exchange program was discontinued. ${ }^{14}$ "The rest [\$74.5 million] seems to have remained in the hands of people who held it after the time fixed by the funding act, hoping that ultimately the notes would be redeemed in full." (Bullock, 1895, p. 138) They would be disappointed.

\section{Post-1790 Agitation for Revising the Redemption of the Continental Dollar}

The evidence presented here identifies $\$ 80.5$ million Continental Dollars as still outstanding in 1790, of which only $\$ 6$ million would be exchanged for bonds in the early 1790 s at the 100 to 1 default rate set by Congress in 1790, basically traded in for next to nothing. But what happened to the other $\$ 74.5$ million Continental Dollars that were still outstanding? The literature on the Continental Dollar assumes that they quietly vanished, that almost none were left around by and after 1790 to be redeemed, and that there were no objections or controversies to its final default in 1790 . Some important yet rarely-considered evidence indicates otherwise.

After passing the Funding Act of 4 August 1790 Congress was bombarded with petitions by holders of Continental Dollars asking Congress to revise its default rate and redeem Continental Dollars at par or at rates better than 100 to 1 . This can be deduced from the advice given to Congress by the Secretaries of the Treasury — who universally and forcefully advocated rejection of these petitions and recommended strict adherence to the 1790 Funding Act. On 22 November 1792, Alexander Hamilton reported to Congress: ${ }^{15}$ 
The SECRETARY OF THE TREASURY, to whom were referred the several petitions specified in the list herewith transmitted, respectfully submits the following report thereupon:

These petitions seek indemnification upon various sums of paper money received from the public during the late war, by the respective petitioners, on account of claims arising upon transactions of that period.

There is no subject upon which the special interposition of the Legislature for relief of particular individuals can be more delicate and dangerous, than that of depreciation; the infinite multitude of cases, in which claims of this nature might, with equal or nearly equal degrees of equity, be supported; the impossibility, from the extraordinary circumstances of the times when those claims originated of during [doing] general justice; the inextricable confusion and incalculable expense of an attempt to redress all the grievances and hardships of that kind which unavoidably took place, afford considerations of the most powerful nature for leaving every question of depreciation where the rules and principles of settlement at the Treasury have left it.

...The magnitude and extreme delicacy of the matter in question appear to render it advisable to adhere to the acts of limitation, as well as the rules of settlement at the Treasury, in this particular, with peculiar caution and strictness.

Such was the policy of the United States in Congress assembled, and a perseverance in that policy is recommended by a variety of weighty reasons.

Similarly, on 23 December 1795, Oliver Wolcott, Jr., Secretary of the Treasury, submitted a report to Congress assessing the "...claims [against the United States] which have not been admitted to be valid..." Class 7 , of the 14 classes of claims, consisted of claims “...founded on bills of credit issued by the authority of the late Government, commonly called bills of the old emission [Continental Dollars]. For these Mr. Nicholson claims payment at par; that is, one specie dollar for every dollar in paper. The only provision hitherto made for this specie of paper is by the act of Congress of the $4^{\text {th }}$ of August, $1790 \ldots$ "Wolcott listed over $\$ 300,000$ in Continental Dollars (face value) being claimed for payment at par-being the claims presented by just three people. Similar petitions asking Congress to redeem ContinentalState Dollars were also made and rejected - see the reports of the Secretaries of the Treasury for 24 December 1795; 26 February 1798; and 25 January $1802 .{ }^{16}$ Apparently, the default enacted 4 August 1790 was neither uncontroversial nor quietly accepted.

But why were people petitioning Congress to revise the 1790 Funding Act? Why had 
they held onto Continental Dollars for so long? Why was there no active market in Continental Dollars? Were they laboring under some particular yet thwarted expectation of redemption?

\section{Speculative Holding versus Trash Disposal of Continental Dollars after 1779}

Continental Dollars began to depreciate sometime in $1776 .{ }^{17}$ Figure 3 shows this depreciation rising at a slow and steady pace from 1777 through late 1778 with it accelerating dramatically thereafter. Most of the depreciation occurred after Congress ceased issuing Continental Dollars in 1779. Holders of Continental Dollars, however, may not have considered this wartime depreciation loss to be permanent. Once the economy returned to normal peacetime conditions, Continental Dollars might be redeemed by the government at face value.

[Place Figure 3 Here]

One reason for such a belief was that, unlike most colonial paper money, Continental Dollars were written to be an explicit contractual obligation to redeem a specific sum of speciewith such being printed on the face of the bill. For example, the following was printed on the $\$ 80$ note: "The Bearer is entitled to receive EIGHTY Spanish milled DOLLARS, or an equal Sum in Gold or Silver according to a Resolution of Congress of the $14^{\text {th }}$ January, 1779" (Newman, 1997, pp. 33-35, 59-68). This can be interpreted as the government setting a fixed exchange rate between specie and Continental Dollars that would be honored when conditions allowed.

The paper money issued by the individual colonies before the Revolution was different. It did not explicitly on its face promise redemption in specie, fix an exchange rate to specie, or guarantee convertibility to specie. ${ }^{18}$ Colonial bills of credit were non-interest-bearing contracts that the issuing government had agreed to accept at face value for payment of the taxes it levied. If more of these bills existed than could be used to pay these taxes and the bills depreciated when used in the marketplace that was just unfortunate for the bill holder. There was no contractual 
obligation of the issuing colony to restore that value in the future even if conditions allowed. Colonial bills of credit were true fiat paper money. The marked difference in the contractual obligations stated on the Continental Dollar may have induced holders to regard it and its future redemption differently than that of traditional bills of credit from the colonial era.

In 1798, the Secretary of the U.S. Treasury admitted that Continental Dollars were contracts that had been violated, albeit by necessity. He said, "This unfortunate depreciation, which operated upon all the paper money... issued during the war, necessitated the United States to adopt principles relative to them which cannot apply in cases of ordinary contract..."19

\section{a. The Stance in Congress over Future Redemption of Continental Dollars}

The possible redemption of Continental Dollars at face value, or at better rates than offered in the marketplace or by the states for tax payments, once the war was over was fostered by statements in Congress. This in turn may have prompted some to hold on to their Continental Dollars rather than remit, trash, or trade them. As early as 22 May and 2 September 1776 such statements as "Whereas, the holders of bills of credit emitted by authority of Congress will be entitled, at certain periods appointed for redemption thereof to receive out of the treasury of the united colonies the amount of the said bills in spanish milled dollars, or the value thereof in gold or silver..." were made by Congress. The periods appointed for redemption were left vague — to be chosen by Congress in the future when conditions allowed. ${ }^{20}$

Hope of future redemption could also be taken from the language of the supreme law of the land. The Articles of Confederation laid before Congress on November of 1777 said that "All bills of credit [Continental Dollars] emitted...under the authority of Congress... shall be deemed... a charge against the United States, for payment whereof the said United States and the public faith are hereby solemnly pledged.” (JCC, v. 9, pp. 924-925) The U.S. Constitution 
adopted by Congress in 1789 maintained this obligation. Article 6 of the U.S. Constitution states that, "All Debts contracted...before the Adoption of this Constitution, shall be as valid against the United States under this Constitution, as under the Confederation."

Congress often considered recommendations about the future disposition of the Continental Dollar — though typically nothing definitive was decided. On 29 December 1778 a motion was made in Congress "Whereas a report hath circulated in divers parts of America, that Congress would not redeem the bills of credit issued by them...but would suffer them to sink in the hands of the holder, whereby the value of the said bills hath...depreciated; and lest the silence of Congress might give strength to the said report; Resolved, That the said report is false..." (JCC, v. 12, pp. 1261-1264) On 14 June 1779 a report was submitted to Congress recommending that the Treasury make up the difference in value in specie-denominated debts paid in depreciated Continental Dollar at the depreciation rate current at the time the debt was paid (JCC, v. 14, p. 732). And on 13 September 1779 the President of Congress, John Jay, issued a public statement wherein he declared that "Having shewn that there is no reason to doubt the ability of the United States to pay their debt... It must be evident to every man who reads the journals of Congress, or looks at the face of one of their bills [Continental Dollars], that Congress have pledged...the redemption of them...it is no more in their power to annihilate your money than your independence, and that any act of theirs for either of those purposes would be null and void." (JCC, v. 15, pp. 1057-1060-italic added)

Congress permanently discontinued emitting Continental Dollars after November of 1779 (Grubb, 2008). On 18 March 1780, Congress gave states a discount when requisitions were paid in specie by the states to Congress. The act stated, "That the several states continue to bring into the continental treasury, by taxes or otherwise, their full quotas... as assigned...the $7^{\text {th }}$ of 
October, $1779 \ldots$ That silver and gold be receivable in payment of the said quotas, at the rate of one Spanish milled dollar in lieu of 40 dollars of the bills [Continental Dollars] now in circulation. That the said bills, as paid in...be not re-issued, but destroyed." (JCC, v. 16, pp. 263265) While phrased as a discount, this act was widely regarded at the time as a "great and deliberate breach of public faith" by Congress. In other words, Congress was viewed as partially, though perhaps temporarily, defaulting on the Continental Dollar. This "discount" applied only to state payments to Congress and would remain the rate at which Congress would credit the states for the payment of their quotas (taxes) owed to Congress from 1780 through $1789 .{ }^{21}$ But what would Congress offer to citizens who held Continental Dollars?

On 28 June 1780, Congress stipulated that on loans denominated in Continental Dollars and made after 1 March 1778 the lender would receive 6 percent interest on what the specie value of those Continental Dollars were at the time they were loaned. The resolution also established a depreciation table for converting Continental Dollars at different dates received into specie dollars. Late in the war, when goods were requisitioned or confiscated from the public, either Continental Dollars, or seemingly more often, loan certificates denominated in Continental Dollars were given as compensation — whatever the requisitioning officer had on hand. ${ }^{22}$ As such, the public may have considered being given government loan certificates as opposed to being given the actual paper money as largely irrelevant. The two instruments had a comparable legal as well as moral standing with regard to congressional commitment. The implication of the 28 June 1780 resolution on loans was that Congress, once it was financially able, would redeem Continental Dollars from the public at what its specie value was in the marketplace at the time it was last received —at best commensurate with the bill's issuing date.

On 26 August 1780 Congress again resolved that “...creditors...be entitled to receive the 
just value of the sums due....according to the current value of continental bills of credit compared with specie at the time the money became due...That all debts due to the United States for monies [Continental Dollars] received...shall be paid according to the just value of the money when it was received..." This position was repeated several times throughout the 1780 s, such as on 16 March 1781 and on 17 May and 3 June 1784. This position indicates that as long as holders of Continental Dollars had received their Dollars before November 1779, they would be entitled to a better rate of redemption than the 40 to 1 rate set by Congress in March of 1780 for payments by the states to Congress and better than any of the rates current in the marketplace or set by the states for payment of taxes in Continental Dollars at that time. ${ }^{23}$

On 12 April 1781 a proposal was laid before Congress which stated “....with respect to the old Emissions [Continental Dollars], Congress may allow 20 years or more for the redemption of it. The faith of the United States pledged by Congress upon issuing those Bills will not be violated by Congress. ... Some who have lost by depreciation will have an opportunity of recovering their losses..." On 18 April 1781, a Congressional Treasury report restated that Congress had promised on 10 April 1780 “...that as soon as the state of the public finances would admit, they would make good to the line of the army...the deficiency of their original pay occasioned by the depreciation of the currency..." (JCC, v. 19, pp. 380-381, 413)

By all accounts Continental Dollars ceased to circulate as a currency around May of $1781 .^{24}$ This outcome was driven by the coincidence of several market forces that reduced demand for Continental Dollars as a currency in the spring of 1781 (Grubb, 2007b). The evidence here adds to these market forces pushing Continental Dollars toward non-circulation. As illustrated in Figure 2, several states by the end of 1782, namely Delaware, Massachusetts, New Hampshire, and Pennsylvania, had completed or were near completing their quotas as 
assigned by Congress for remitting Continental Dollars to the Treasury. Since no state remitted more than its quota, once the quota was filled that state must have stopped accepting Continental Dollars. ${ }^{25}$ For residents of such states still holding Continental Dollars, this meant that the primary demander of their Continental Dollars had stopped accepting them. For some, the transaction and exchange costs of moving their Continental Dollars to states with unfilled quotas who were still accepting Continental Dollars for tax payments would have been too high to justify such moves, thus reducing their value as a circulating currency. ${ }^{26}$

But more importantly, the evidence here indicates that by the spring of 1781 many expected that Congress, when financially able, would redeem Continental Dollars in specie at their market exchange value at the time when that Continental Dollar was last received. Given the rapidly depreciating value of Continental Dollars to specie dollars in the marketplace, illustrated in Figure 3, this expectation created the incentive to stop trading Continental Dollars. For example, one Continental Dollar received in early 1778 would be expected to be redeemed by Congress in the near future for about 0.25 specie dollars. If that exact same physical Continental Dollar was transferred to someone else in the marketplace in early 1781, it would be expected to be redeemed by Congress in the near future for only about 0.025 specie dollars. The fall in expected redemption value was likely to be greater than any loss due to time discounting (lost interest) from holding this claim. Clearly the incentive for many was to hold on to their Continental Dollars and not trade or circulate them in the marketplace - unless they were under extreme liquidity pressure to raise cash in specie.

Through the rest of the 1780s up to the Constitutional Convention, the disposition of the Continental Dollar continued to be considered by Congress, but with no definitive action taken. On 25 April 1781, Oliver Wolcott introduced a motion in Congress stating that the 
$\ldots 200,000,000$ of dollars emitted [by Congress] before the $18^{\text {th }}$ of March 1780 and hereby intended to be redeemed...shall be paid in Spanish milled Dollars or other gold and silver equivalent thereto, or in the Bills of credit emitted by Congress as aforesaid [the Continental-State currency]. ... that from and after the expiration of the aforesaid twenty years if any of the said Bills of credit emitted by Congress before the $18^{\text {th }}$ of March 1780 and hereby intended to be redeemed, shall remain outstanding, the holder or holders of such Bills shall be entitled to and shall be paid by the Treasurer of the United States for the time being, the value thereof in gold and silver equal to Spanish Milled Dollars, or in Spanish milled Dollars according to the nominal value declared in the said Bills of credit, on demand... with Interest thereon. (JCC, v. 20, p. 439)

The motion was debated and rejected on 2 May 1781 (JCC, v. 20, p. 471).

Likewise, a motion proposed on 18 September 1782 that "Old Continental Money" be credited to the states "....according to the current value thereof compared with Gold and Silver at the time when such State had delivered over its proportion..." was referred to committee and not acted on. On 22 May 1783 a motion was presented to Congress "... for calling in the old emission bills [Continental Dollars], ... and to give certificates to the possessors for the amount thereof in specie at the rate of one silver dollar for seventy five continental dollars, bearing interest at the rate of six per cent per annum..." (JCC, v. 23, p. 591; v. 24, pp. 357-358) This motion was also referred to committee and not acted on.

On 17 May 1784 a "Grand Committee" of Congress submitted to Congress the following resolution (written by Thomas Jefferson):

That all sums of Continental bills of credit paid by or to any State, ... shall be credited or debited in account according to the specie value of such bills at the time of payment, as settled by the legislature of the same state... on which payments an interest shall be allowed at the rate of six per centum per annum from the time of paiment.

That all such bills now in the treasury of any state, shall be credited to such state at the value they bore in specie, at the time they were received by the State ...

That all such bills now in the hands of individuals shall be redeemed at the same rates... That the holders of such bills shall be at liberty to carry them to the loan officer of the United States within their State, who shall give them in Exchange for the same, a certificate expressing the sum in specie, which the United States owes in lieu thereof and the time from which it bears interest... where the said bills were received before that day, where received afterwards, the time of their actual receipt. The Loan officer shall require from the holder, the best evidence of the time of his receiving them which the nature of 
the case will admit... and giving thereto so much credit as in his conscience he shall think it deserves; ... These certificates shall be funded and paid as the other debts of the United States. (JCC, v. 26, pp. 395-396)

This motion was also assigned to committee and not acted on.

Similarly, on 3 June 1784, another report by a different committee was submitted to Congress that recommended, "That if bills of credit advanced to any State or person to be expended for the use of the United States, shall have depreciated before the same were so applied, the receiver shall not be charged with the depreciation, if satisfactory evidence be given...that such bills had not been applied to any other use..." (JCC, v. 27, p. 541) This proposal does not appear to have been acted on by Congress.

On 29 July 1785 , regarding a motion to send commissioners out to the various states to settle the accounts between the states and Congress, an amendment was proposed, and its substance adopted, that said (JCC, v. 29, pp. 590-593):

Provided also, that nothing in this resolve contained, shall be construed to authorize the commissioners...to settle or liquidate any demand against the United States, for any sum or sums of continental bills of credit, emitted prior to the $18^{\text {th }}$ of March, 1780, either in the hands of individuals states respectively, or of their citizens, until the United States in Congress assembled, shall have given a particular decision at what rate the same shall be redeemed by the United States.

Petitions also came into Congress from time to time, such as that of David Woelper on 3 January 1786, requesting a new settlement with regard to the depreciation of Continental Dollars from what the petitioner had accepted in a prior period. Congress stated that "the Committees of Congress uniformly reported against a revisal of settled accounts." (JCC, v. 30, p. 11-italics added) As such, there was an incentive not to settle one's account too soon.

In conclusion, what Congress would do about the Continental Dollar was left continually undecided through the mid-1780s. Thus, hope of future redemption at better rates than in the marketplace remained. In addition, the prominent expectation given by Congress was that 
Congress, when financially able, would redeem Continental Dollars at their specie value in the marketplace when last acquired. Given the rising depreciation rates in the marketplace, the public's incentive regarding Continental Dollars acquired prior to 1779 would be not to trade them in the marketplace or use them to pay state taxes or trash them, but to hold them for future redemption. For Continental Dollars acquired in the marketplace after 1779, it would be better to use them to pay state taxes where possible. There was also an incentive not to rush to settle an account too early, but to wait for better days. In part, these incentive-signals sent by Congress, especially in 1780 and 1781, may help explain both why Continental Dollars ceased to circulate as currency in the marketplace after mid-1781 and why some people in the 1780 s used them to pay state taxes while others held onto them as a speculative investment.

\section{b. Statements and Advice from the Founding Fathers Regarding Future Redemption}

Statements by some founding fathers also held out the possibility of redemption of Continental Dollars by the Federal Government in the near future at face value or better rates than were current in the marketplace. For example, Benjamin Franklin advised, in his essay $O f$ the Paper Money of America written while in Paris sometime between 1780 and 1784, that:

First, The Quantity of Bills [Continental Dollars] borrowed before the Depreciation...The Principal of this Sum is considered as equal in Value to so many Dollars of Silver as were borrowed in Paper, and will be paid in Silver accordingly.

Secondly, The Quantities of Bills borrowed in different Stages of the Depreciation down to the present time. These Sums are by a Resolution of Congress to be repaid in Silver according to the Value they were in Silver at the Time they were lent...Thus those Lenders have their Property secured from the Loss by Depreciation subsequent to the Time of their Loan. (Oberg, 1998, p. 232; see also Smyth, 1907, pp. 112-113)

Along a similar vein, Thomas Jefferson writing to James Madison from Annapolis on 25 April 1784 under the suspicion that future redemption would be at better rates than what prevailed currently in the marketplace, reasoned thus (Boyd, 1953, v. 7, p. 120):

Would it not be well for Virginia to empower persons privately to buy up her 
quota of old Continental money. I would certainly advise this were I not afraid that possession of her quota on such easy terms would tempt her to refuse justice to the other states on this matter. ... If she would...do what is right, I should much wish to see her adopt secret measures for the purchase. I think some states will do this, and I fear with unjust views.

From Annapolis, Jefferson wrote again to Madison on 8 May 1784 and in answer to Madison's question "Has any resolution been taken by Congress touching the old Continental Currency?" said:

That question has been debated by a grand Committee upwards of a month. They yesterday came to the inclosed resolution. It was decided by only 6 votes against 5 . I think it will gain strength in the House. The Southern and middle states I believe are for it, and I think one or two of the Eastern may perhaps come over. Yet there is far from being a certainty of this. (Boyd, 1953, v. 7, pp. 123, 232)

Foreign observers also noted the possibility of a future redemption as well as the uncertainty over its timing and manner. As one foreign observer put it on 4 May 1784, in reference to the Continental Dollar, "At present there are many private Gentlemen holding large sums of Paper money, that is to be called in. But when this will happen, at what rate it will be redeemed, congress do not yet agree upon.” (Boyd, 1953, v. 7, p. 213)

On 3 June 1784 the Continental Congress received a committee report on settling the accounts of the State of Pennsylvania with the United States that recommended:

That all monies or articles supplied by the United States to any particular State, shall be charged to such State at their just value in specie, with an interest of six per cent per annum, from the date of such supplies, until the final adjustment and payment of account; ...

That if bills of credit [Continental Dollars] advanced to any State or person to be expended for the use of the United States, shall have depreciated before the same were so applied, the receiver shall not be charged with the depreciation, if satisfactory evidence be given to the Commissioner by such receivers, that such bills had not been applied to any other use, (and were applied to the purpose designed, as soon as occasion required); otherwise such receiver will be chargeable with such bills at their value when received... (JCC, v. 27, pp. 540-545)

No vote is recorded as to whether Congress accepted or rejected the resolutions of this 
committee. While directed only at the particular case of the State of Pennsylvania, the general principle would appear to offer holders of Continental Dollars the expectation that this paper money would be redeemed in specie at the Continental Dollar-to-specie exchange rate current when the holders received their bills (with interest between then and final settlement). This was Jefferson's interpretation and the basis of his advice to holders of Continental Dollars.

In a series of letters to French correspondents in 1786 Jefferson, who was still in Paris at the time, explained his current understanding of the likely redemption of Continental Dollars. On 3 June 1786, he advised (Boyd, 1954, v. 9, pp. 604-605):

It is six years since the paper money of New England has ceased to circulate as money. It is considered at present as making a part of the National debt, and that the holders of it will be entitled to receive from the public as much gold or silver as the paper money would have bought at the time it was received by the holder with an interest of 6 per cent per annum. But as yet no precise arrangements have been taken for the paiment either of principal or interest. Most of the subjects of France, having paper money, have deposited it in the hands of the French minister or Consul at New-York, that paiment may be demanded whenever it shall be provided by Congress. There are even speculators in America who will purchase it. But they give much less than it is worth. As for myself I do not deal in it.

On 11 July 1786 he explained that (Boyd, 1954, v. 10, pp. 127-128):

It is true that the United states, generally, and most of the separate states in particular, are endeavoring to establish means to pay the interest of their public debt regularly, and to sink it's principal by degrees. But as yet their efforts have been confined to that part of their debts which is evidenced by certificates. I do not think that any state has yet taken measures for paying their paper money debt. The principle on which it shall be paid I take to be settled, tho' not directly yet virtually, by the resolution of Congress of June 3,1784 , that is that they will pay the holder or his representative what the money was worth at the time he received it, with an interest from that time of 6 per centum per annum. ... whether the money was... Continental money, or Virginia money;...-I advise all foreign holders of paper money to lodge it in the office of their Consul for the state where it was received, that he may dispose of it for their benefit the first moment that paiment shall be provided by the state or Continent [Continental Congress].

On 6 November 1786 he explained further that (Boyd, 1954, v. 10, p. 509):

Congress have as yet come to no resolution as to the general redemption of paper money. That it is to be redeemed is a principle of which there is no doubt in the mind of 
any member of Congress, nor of any citizen of the United States. A Resolution of Congress taken in a particular case, which stood on the same ground on which the general one will stand, founds a presumption amounting nearly to certainty that they will pay the holder of every bill what it cost him, or the persons whom he represents, at the time of receiving it, with an interest of 6 per Cent. They have of course established no rules of evidence as to the time of receiving the money.

And lastly, on 8 December 1786 he explained even further that (Boyd, 1954, v. 10, p. 584):

As to the paper money in your hands, the states have not yet been able to take final arrangements for it's redemption. But soon as they shall have gotten their finances into some order, they will surely pay for it what it was worth in silver at the time you received it, with an interest. The interest on Loan office certificates is I think paid annually in all states; and in some of them they have begun to make paiments of the principal. These matters are managed for foreigners by the Consul of their nation in America, where they have not a private friend to attend for them. ${ }^{27}$

This material establishes, contrary to what often assumed in the literature, that the disposition of the future redemption of Continental Dollars remained an open question throughout the 1780s. Certainty over its future was continually avoided by Congress, though it sent reasonable expectations that redemption would happen in the near future when Federal finances were in better shape, and would happen, if not at face value, at least at a better rate for those who received their Dollars prior to 1780, than the 40 to 1 rate set by Congress in 1780 . Such an expectation created an incentive to hold Continental Dollars, those received prior to 1780 , for future redemption rather than to trade them in the marketplace or remit them in state taxes. As such, the $\$ 80.5$ million Continental Dollars still outstanding and unredeemed in 1790 (40 percent of the total emitted) should not be a surprising sum.

With the Funding Act of 4 August 1790, Congress committed to irrevocably defaulting on the Continental Dollar. After 1790, however, Congress was continually presented with petitions asking it to un-default the Continental Dollar. The Secretaries of the Treasury, Alexander Hamilton and then subsequently Oliver Wolcott Jr. and Albert Gallatin, advocated a strict hard line on not un-defaulting the Continental Dollar, and advised Congress to stick to the 
default rate set by the 1790 Funding Act, i.e. to maintain the irrevocable nature of the default. Why did they take this strict hard line in their advice to Congress?

\section{Discrimination and the Reason for Irrevocable Default}

In 1790, under the auspices of the new U.S. Constitution that allowed Congress to create a direct tax revenue source for itself, Congress moved to fund (un-default) its obligations. How to pay its obligations generated a contentious debate in Congress over whether to credit current holders with the full face value of the obligation even if they had paid a pittance for it in the marketplace earlier, or whether original holders of the debt should be given something to make up for their loss when they were "forced" to sell the obligation at below face-value prices in the pre-1789 marketplace. This issue is referred to as the debate over discrimination. ${ }^{28}$

With regard to interest-bearing debt obligations (bonds), Congress decided that current holders would get full face-value - that is interest paid in specie, including arrears of interest, on the full face value in the form of callable perpetuities - and original holders of the debt would get nothing. ${ }^{29}$ With regard to non-interest-bearing obligations (the Continental Dollar), Congress decided that original holders would get nothing, and current holders would get less than 1 cent on the dollar of face value in the form of a required exchange for interest-bearing bonds.

The winning argument put forward for funding the interest-bearing debt at face value, with no discrimination between original and current holders, was that the new U.S. Constitution obligated the Federal Government to honor its prior obligations as originally contracted, i.e. honor the face value, and that such was necessary for reestablishing the creditworthiness of the government. Discrimination, besides being impractical, was at odds with honoring the obligation as a contract that was transferable in the marketplace and upholding the negotiability of government instruments (Taylor, 1950). But these arguments hold equally well for paying off the 
Continental Dollars still outstanding at face value to the current holders.

The predominant expectation fostered by Congress throughout the 1780s was that the redemption of the Continental Dollar would be at its specie value when last received by the current holder. Such redemption, however, would be analogous to discrimination in funding the bond debt, i.e. equivalent to giving current bond holders interest on only the market price of the bond when last purchased as opposed to giving the current holder interest on the full face value of the bond. It would be setting the issuer's contractual obligation to the current holder of said contract to be whatever the market value of the obligation was when last purchased or received by the current holder rather than setting it to be the face value of the contract. If Congress denied discrimination on its interest-bearing debt, consistency required that Congress also deny redeeming Continental Dollars at their market value in specie when last acquired. Policyconsistency required that only Continental Dollars in the hands of their current holders could be considered for redemption and only at either face value or at nothing at all. As argued elsewhere (Grubb, 2007a), redemption at face value was outside the revenue capabilities and asset position of Congress. Thus, nothing, or as close to nothing as one could get, had to be the choice in 1790 .

With its new power to directly tax the public, Congress could have accepted Continental Dollars in payment of the taxes it levied on the public after 1789, effectively un-defaulting this debt. Instead, Congress decided in 1790 not to accept its Continental Dollars directly from the public in payment of its taxes at any rate, because to do so would have substantially reduced Congress' specie revenues in the near term, and so undercut the credibility of its commitment to funding its interest-bearing debt (payment of which was to be in specie).

Thus, the Continental Dollar had to remain unredeemed in 1790. Grubb (2007a) explains how an irrevocable default on the Continental Dollar could be done at this juncture without 
jeopardizing the Federal Government's future creditworthiness. Adding to that explanation the necessity of being consistent with its anti-discrimination position on funding its interest-bearing debt helps establish that the actions of Congress regarding debt-funding in 1790 were rational, coherent, and consistent, and not necessarily capricious or purely rent-seeking behavior.

\section{Conclusion}

The history of the Continental Dollar is important to understanding the U.S. financial revolution. If nothing else, it influenced debate over monetary powers at the 1787 Constitutional Convention (e.g. see Calomiris, 1988; Grubb, 2006, 2007a; Holton, 2007). This history, however, has remained murky — especially regarding the redemption of the Continental Dollar after 1779. The behaviors and motives of Congress and the public have been either ignored or explained in such a way that they appear capricious and irrational. The evidence here turns their motives and behaviors into those of rational, coherent, and consistent actors. It also documents the exact time path and location by state of the redemption of Continental Dollars. The continuing presence of the Continental Dollar well into the 1790s was an important consideration and constraint on the Founding Fathers' efforts to salvage the nation's financial position. 


\section{References}

American State Papers. Class III, Finance, Vol. 1. [Documents, Legislative and Executive of the Congress of the United States, Vol. 5 (Washington: Gales and Seaton, 1832)].

American State Papers. Class IX, Claims, Vol. 1. [Documents, Legislative and Executive of the Congress of the United States, Vol. \{blank\} (Washington: Gales and Seaton, 1834)].

Archives of Maryland, Vols. 1-72. (Baltimore, MD: Maryland Historical Society, 1883-1972).

Atack, Jeremy, and Peter Passell, A New Economic View of American History. New York: W. W. Norton, $2^{\text {nd }}$ edition, 1994.

Bezanson, Anne, Prices and Inflation during the American Revolution: Pennsylvania, 17701790. Philadelphia: University of Pennsylvania Press, 1951.

Bolles, Albert S., The Financial History of the United States from 1774 to 1789, Vols. 1-3. New York: Augustus M. Kelly, 1969 [original 1884].

Boyd, Julian P., The Papers of Thomas Jefferson. Princeton, NJ: Princeton University Press, Vols. 7-12, 1953-1955.

Breck, Samuel, Historical Sketch of Continental Paper Money. Philadelphia: John C. Clark, 1843.

Bronson, Henry, “A Historical Account of Connecticut Currency, Continental Money, and the Finances of the Revolution," Papers of the New Haven Colony Historical Society, 1, (1865), pp. 1-192 [New Haven, CT: Thomas J. Stafford, printer].

Bullock, Charles J., The Finances of the United States from 1775 to 1789, with Especial Reference to the Budget. Madison, WI: University of Wisconsin Press, 1895.

Bullock, Charles J., Essays on the Monetary History of the United States. New York: Macmillan, 1900 .

Carp, E. Wayne, To Starve the Army at Pleasure. Chapel Hill, NC: University of North Carolina Press, 1984.

Calomiris, Charles W., "Institutional Failure, Monetary Scarcity, and the Depreciation of the Continental," Journal of Economic History, 48 (Mar. 1988), pp. 47-68.

Cooke, Ebenezer, Sotweed Redivivus: Or the Planters Looking-Glass. Annapolis, MD: William Parks Printer, 1730. 
Elliot, Jonathan, "Funding System of the United States and Great Britain," House of Representatives Document No. 15 (Vol. II. Executive Documents), $28^{\text {th }}$ Congress, $1{ }^{\text {st }}$ Session, Read on Dec. 16, 1843.

Ferguson, E. James, The Power of the Purse. Chapel Hill, NC: University of North Carolina Press, 1961.

Ferguson, E. James, et al., eds., The Papers of Robert Morris, 1781-1784, Vols. 1-9. Pittsburgh, PA: University of Pittsburgh Press, 1973-1999.

Garber, Peter M. “Alexander Hamilton's Market-Based Debt Reduction Plan,” CarnegieRochester Conference Series on Public Policy, 35 (1991), pp. 79-104.

Gouge, William M., A Short History of Paper Money and Banking in the United States. Philadelphia, PA: T. W. Ustick, 1833.

Grubb, Farley, "The U.S. Constitution and Monetary Powers: An Analysis of the 1787 Constitutional Convention and the Constitutional Transformation of the U.S. Monetary System," Financial History Review, 13, no. 1 (Apr. 2006), pp. 43-71.

Grubb, Farley, "The Net Worth of the U.S. Federal Government, 1784-1802," American Economic Review-Papers and Proceedings, 97, no. 2 (May 2007a), pp. 280-284.

Grubb, Farley, “The Continental Dollar: How Much Was Really Issued?” NBER Working Paper, No. 13047, December 2007b [http://www.nber.org/papers/w13047].

Grubb, Farley, “The Continental Dollar: How Much Was Really Issued?” Journal of Economic History, 68, no. 1 (Mar. 2008), forthcoming.

Harlow, Ralph Volney, “Aspects of Revolutionary Finance, 1775-1783,” American Historical Review, 35 (Oct. 1929), pp. 46-68.

Holton, Woody, Unruly Americans and the Origins of the Constitution. New York: Hill and Wand, 2007.

Hughes, Jonathan, and Louis P. Cain, American Economic History. New York: Pearson Education Inc., $7^{\text {th }}$ edition, 2007.

Journals of the Continental Congress, 1774-1789. Vols. 1-34. Washington D.C.: Government Printing Office, 1904-1937.

Newman, Eric P., The Early Paper Money of America. Iola, WI: Krause Publications, 1997 [4 ${ }^{\text {th }}$ edn.]. 
Nourse, Joseph, “Amount of Continental Money Issued During the Revolutionary War and the Depreciation of the Same," House Document No. 107, $20^{\text {th }}$ Congress, ${ }^{\text {st }}$ Session, January 30, 1828. Washington D.C.: Gales \& Seaton, 1828.

Oberg, Barbara B., ed., The Papers of Benjamin Franklin, Vol. 34. New Haven, CT: Yale University Press, 1998.

Perkins, Edwin J., American Public Finance and Financial Services, 1700-1815. Columbus, OH: Ohio State University Press, 1994.

Phillips, Henry Jr., Continental Paper Money: Historical Sketches of American Paper Currency, Second Series. Roxbury, MA: W. Elliot Woodward, 1866.

Ratchford, B. U., American State Debts. Durham, NC: Duke University Press, 1941.

Scott, Kenneth, Counterfeiting in Colonial America. Philadelphia: University of Pennsylvania Press, 1957.

Sumner, William Graham, The Financier and the Finances of the American Revolution, Vols. 12. New York: Augustus M. Kelly, 1968 [original 1891].

Smyth, Albert Henry, The Writings of Benjamin Franklin, Vol. 9. London: Macmillan, 1907.

Syrett, Harold C., ed., Papers of Alexander Hamilton. New York: Columbia University Press, Vols. 2-17, 1961-1972.

Taylor, George Rogers, ed., Hamilton and the National Debt. Boston: D.C. Heath and Company, 1950.

Tindall, George Brown, America: a Narrative History. New York: W. W. Norton (2 ${ }^{\text {nd }}$ edn.), 1988.

United States Congress, The Debates and Proceedings in Congress of the United States, Vols. 118. Washington, D.C.: Gales \& Seaton, 1834-1856.

Walton, Gary M., and Hugh Rockoff, History of the American Economy. Mason, OH: SouthWestern, $10^{\text {th }}$ edition, 2005.

Webster, Pelatiah, Political Essays on Nature and Operation of Money, Public Finances, and Other Subjects. New York: Burt Franklin, 1969 [original 1791]. 


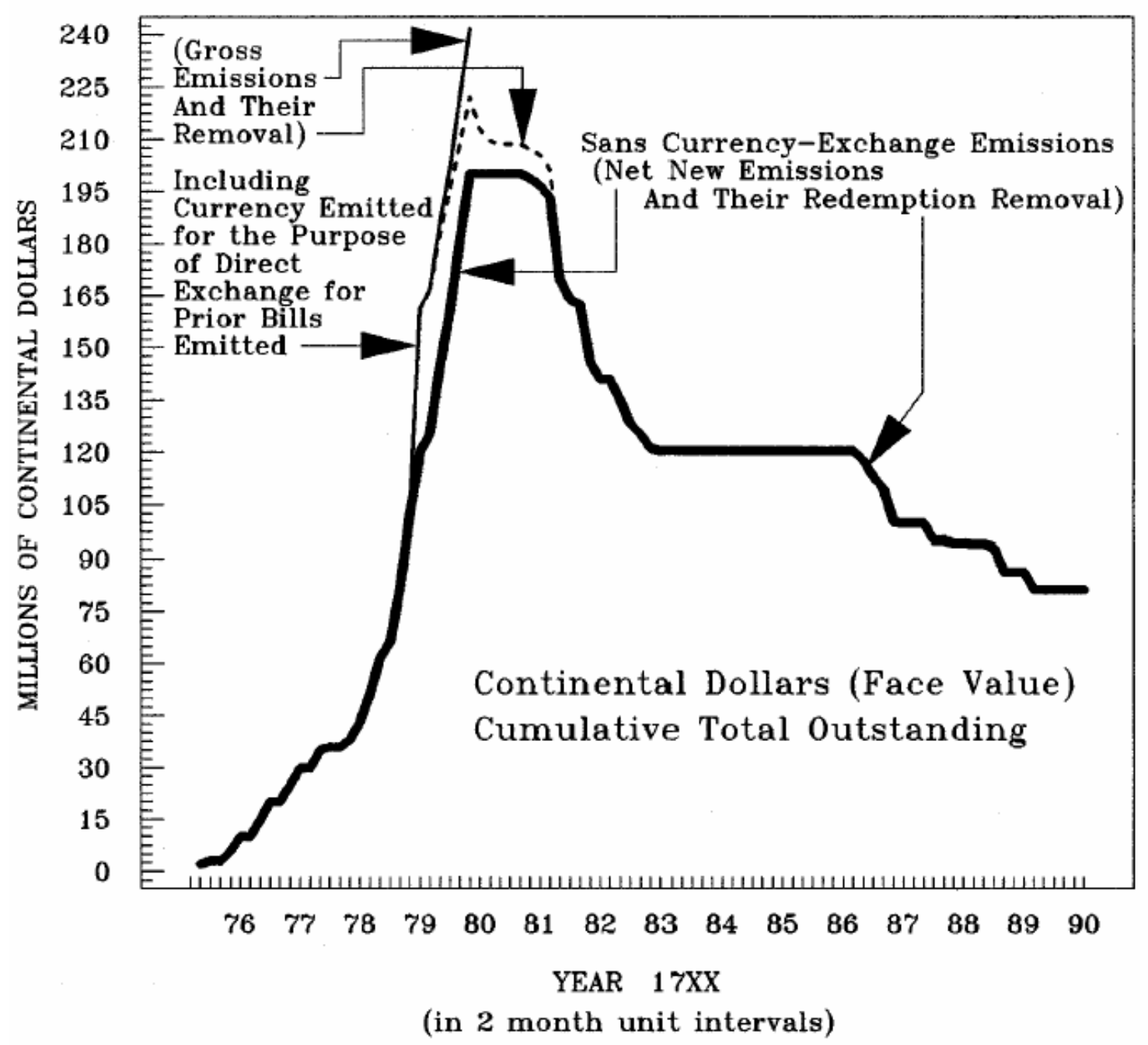

Fig. 1 The Continental Dollar, 1775-1790: Cumulative Outstanding

Totals Emitted and Removed-Face Value

Sources: See Grubb (2007b, 2008); Table 2; and the text.

Notes: The two-month unit intervals combine January with February, March with April, and so on. 


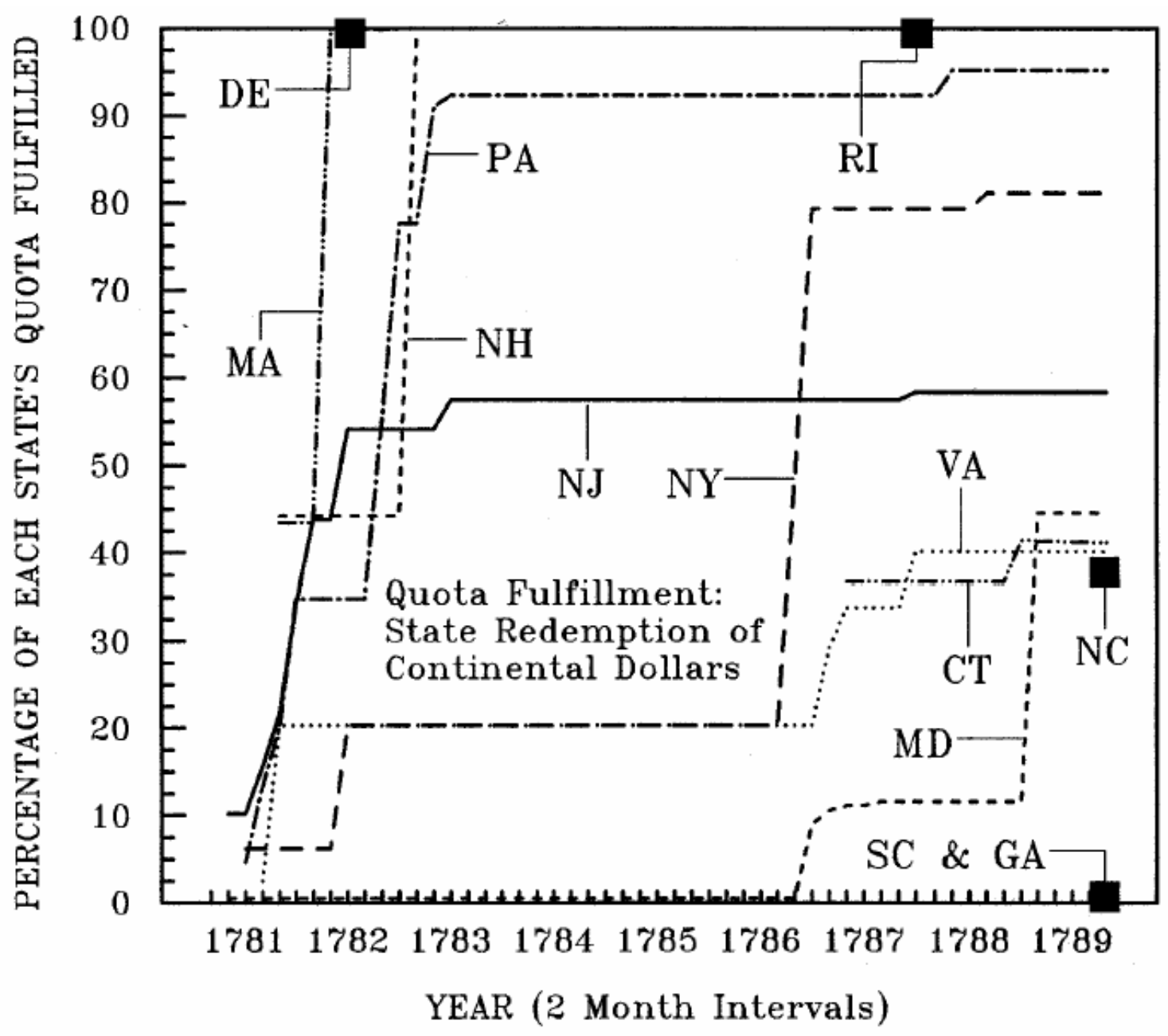

Fig. 2 Progress in Quota Fulfillment by States in Redeeming Continental

Dollars, 1780-1789

Sources: Tables 1 and 2.

Notes: See the text for construction. Square markers indicate that only a single payment was observed for that state. Lines start at the first payment remitted for each state, respectively, and chart the cumulative progress in fulfilling that state's assigned quota (see Table 1). The twomonth unit interval counts January with February, March with April, and so on. 


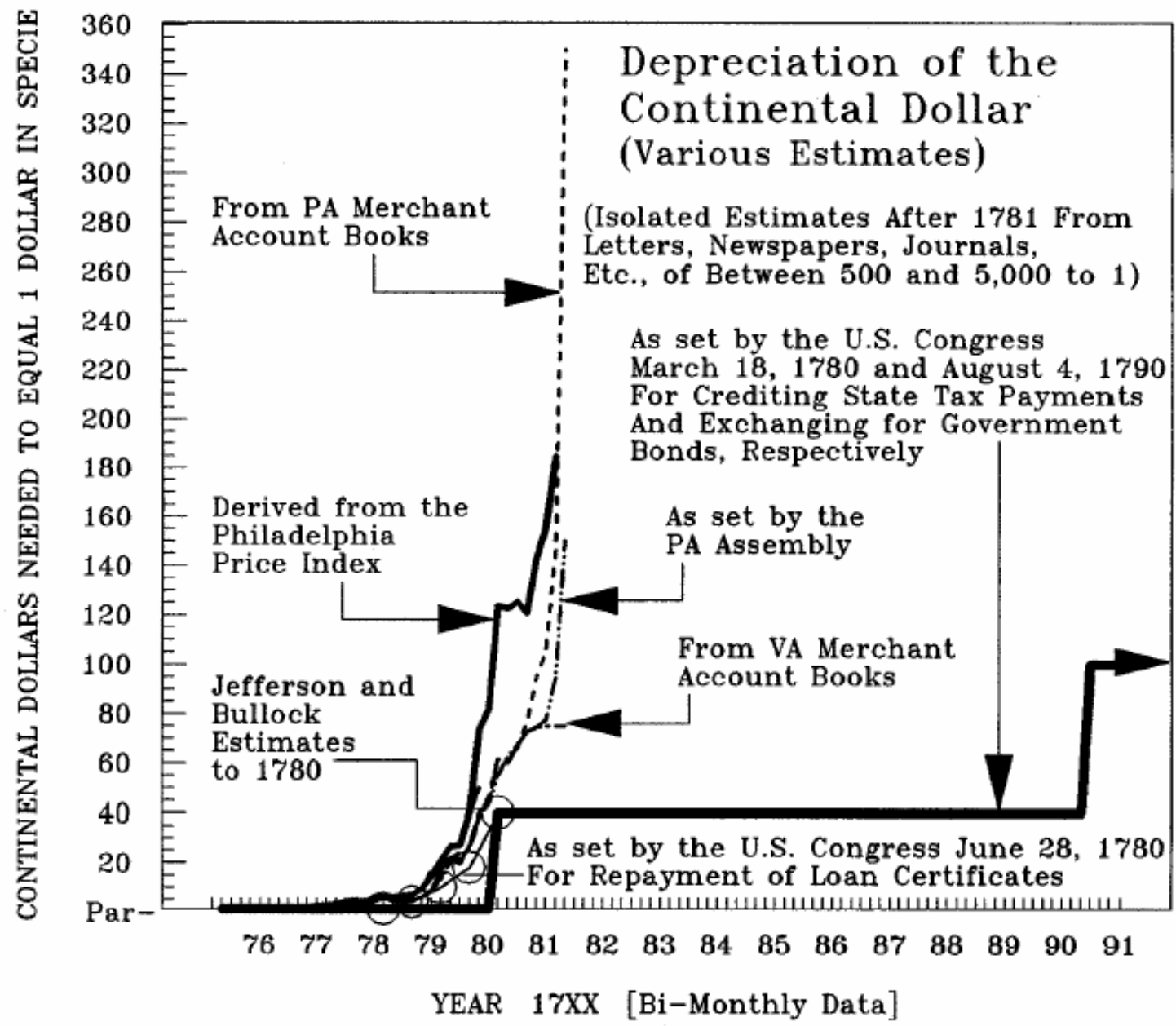

Fig. 3 The Depreciation of the Continental Dollar: 1775 through 1790

Sources: Bezanson (1951, p. 344); Boyd (1954, v. 10, pp. 42-43); Bullock (1895, p. 135); JCC (v. 16, p. 264; v. 17, pp. 567-569); United States Congress (1834, v. 2, pp. 2243-2251); Webster (1969, pp. 501-502). See also Grubb (2007b).

Notes: Bullock (1895, p. 134) reports the highest depreciation rate found in any state. The Philadelphia price index is a 15 commodity weighted arithmetic index for prices in Continental Dollars and stops in April 1781. The index as reported is divided by 100 to get the number reported here. For the isolated exchange rates reported after 1781, see Bolles (1969, v. 1, pp. 117-146), Boyd (1954, v. 10, p. 26), Gouge (1833, II, p. 26), Phillips (1866, pp. 182-184), Sumner (1968, v. 1, pp. 95-96), and Webster (1969, p. 502). 
Table 1. Quota of Continental Dollars Assigned to Each State to be Redeemed

\begin{tabular}{lrl}
\hline State & Quota Assigned & Quota Completed \\
\hline New Hampshire & $\$ 5,200,000$ & September 18, 1782 \\
Massachusetts & $29,900,000$ & August 31, 1782 \\
Rhode Island & $2,600,000$ & August 13, 1787 \\
Connecticut & $22,100,000$ & \\
New York & $9,750,000$ & \\
New Jersey & $11,700,000$ & January 7, 1782 \\
Pennsylvania & $29,900,000$ & \\
Delaware & $2,210,000$ & \\
Maryland & $20,540,000$ & \\
Virginia & $32,500,000$ & \\
North Carolina & $13,000,000$ & \\
South Carolina & $15,600,000$ & \\
Georgia & {$[\mathrm{unlisted]}$} & \\
& $\$ 195,000,000$ & \\
& & \\
\end{tabular}

Sources: Ferguson, et al. (1973, v. 1, p. 194); JCC (v. 15, p. 1150); Table 2.

Notes: The total amount of Continental Dollars that Congress thought it had emitted was \$200 million - the last emission being 29 November of 1779, but due to an accounting error the actual total was $\$ 199,990,000$ (Grubb, 2007b, 2008). Presumably the unstated amount to be assigned to Georgia reflects the difference between the $\$ 195$ million listed above and the total Congress thought it had emitted. 
Table 2. Continental Dollars Paid by each State from 1779 through 1790 to the Federal Government as Part of Their Tax Revenues and Currency Swaps Owed to Congress That Were Examined, Counted, and then Burnt By the U.S. Treasury (Face Value in Nominal Dollars)

\begin{tabular}{|c|c|c|c|}
\hline \multirow{2}{*}{$\begin{array}{l}\text { Year } \\
\text { Month } \\
\text { Day }\end{array}$} & \multicolumn{2}{|c|}{$\begin{array}{l}\text { Reported by Joseph Nourse, Registrar } \\
\text { of the U.S. Treasury, } 14 \text { January } 1786 .\end{array}$} & \multirow[t]{2}{*}{$\begin{array}{l}\text { Reported by Alexander } \\
\text { Hamilton, Secretary of the } \\
\text { U.S. Treasury, } 11 \text { May } 1790 \\
\text { Received From Amount }\end{array}$} \\
\hline & From Whom Received & Amount & \\
\hline \multicolumn{4}{|l|}{1779} \\
\hline \multirow[t]{3}{*}{ May } & Delaware State Treasurer & 224,524 & \\
\hline & Pay Master-General's Dept. & 233,098 & \\
\hline & Pennsylvania State Treasurer & 166,000 & \\
\hline \multirow[t]{7}{*}{ June } & New York-Loan Office & $1,841,856$ & \\
\hline & New Jersey_Loan Office & 768,466 & \\
\hline & Pennsylvania-Loan Office & 73,600 & \\
\hline & Delaware State Treasurer & 150,003 & \\
\hline & Delaware-Loan Office & 157,894 & \\
\hline & Pay Master-General's Dept. & 24,851 & \\
\hline & Board of War & 83,233 & \\
\hline \multirow[t]{4}{*}{ July } & Rhode Island-Loan Office & 746,372 & \\
\hline & Rhode Island State Treasurer & 195,018 & \\
\hline & New Jersey_Loan Office & 483,444 & \\
\hline & Pennsylvania-Loan Office & 537,401 & \\
\hline \multirow[t]{2}{*}{ Sept. } & Massachusetts_-Loan Office & $6,635,550$ & \\
\hline & Pay Master-General's Dept. & 15,335 & \\
\hline Oct. & New Jersey_Loan Office & 554,505 & \\
\hline Nov. & New York-Loan Office & 5,130 & \\
\hline \multirow[t]{2}{*}{ Dec. } & Pennsylvania-Loan Office & $1,397,002$ & \\
\hline & Virginia-Loan Office & $4,848,100$ & \\
\hline \multicolumn{4}{|l|}{1780} \\
\hline \multirow[t]{2}{*}{ Jan. } & Connecticut-Loan Office & $1,592,159$ & \\
\hline & Connecticut State Treasurer & $1,367,537$ & \\
\hline Feb. & Pennsylvania-Loan Office & $6,220,313$ & \\
\hline \multirow[t]{2}{*}{ Mar. } & Rhode Island State Treasurer & 8,238 & \\
\hline & Pennsylvania-Loan Office & $1,445,914$ & \\
\hline
\end{tabular}


Delaware-Loan Office

South Carolina-Loan Office

June New Hampshire State Treasurer

New Hampshire-Loan Office

Pay Master-General's Dept

Managers of the U.S. Lottery

Nov. New Jersey-Loan Office

Maryland-Loan Office

$25^{\text {th }}$

$25^{\text {th }}$

Dec. New Jersey-Loan Office

$23^{\text {rd }}$

\section{1}

Jan. New York-Loan Office $1^{\text {st }}$

Feb. Pennsylvania-Loan Office $13^{\text {th }}$

Mar. New Jersey_Loan Office $23^{\text {rd }}$

Apr. Pennsylvania-Loan Office Virginia-Loan Office Virginia-Loan Office

$3^{\text {rd }}$

$17^{\text {th }}$

May Pennsylvania-Loan Office Virginia-Loan Office New Jersey-Loan Office

$15^{\text {th }}$

$29^{\text {th }}$

$30^{\text {th }}$

June New Hampshire-Loan Office Massachusetts_-Loan Office

$11^{\text {th }}$

$11^{\text {th }}$

July Massachusetts-Loan Office Massachusetts State Treasurer
3,899

$1,814,471$

200,000

501,522

8,893

184,513

949,430

115,117

New Jersey $\quad 949,430$

Maryland $\quad 115,117$

237,840

New Jersey $\quad 237,840$

599,396

New York 599,396

$1,400,527$

Pennsylvania $\quad 1,400,527$

631,523

New Jersey $\quad 631,523$

$2,599,987$

$105,433 *$

802,717

Pennsylvania $\quad 2,599,987$

Virginia

802,717

$1,999,995$

$5,785,555$

712,824

Pennsylvania $\quad 1,999,995$

Virginia $\quad 5,785,555$

New Jersey $\quad 712,824$

2,299,769

$12,984,687^{\mathrm{a}}$

New Hampshire 2,299,769

Massachusetts $12,984,001^{\mathrm{a}}$

$46,959 *$

$821,152 *$ 
$\begin{array}{ll}\text { Aug. } & \begin{array}{l}\text { New Jersey-Loan Office } \\ \text { Pennsylvania-Loan Office }\end{array} \\ 2^{\text {nd }} & \text { Pennsylvania-Loan Office } \\ 4^{\text {th }} & \\ \begin{array}{l}\text { Oct. } \\ 6^{\text {th }}\end{array} & \text { New Jersey-Loan Office } \\ \text { Nov. }_{6^{\text {th }}} & \text { Massachusetts-Loan Office }\end{array}$

1782

Jan. Delaware-Loan Office

New York-Loan Office

New York-Loan Office

$7^{\text {th }}$

$30^{\text {th }}$

South Carolina-Loan Office

Feb. New Jersey-Loan Office

$23^{\text {rd }}$

May Pennsylvania-Loan Office

$30^{\text {th }}$

Delaware-Loan Office

June Pennsylvania-Loan Office

$3^{\text {rd }}$

July Pennsylvania-Loan Office $30^{\text {th }}$

Aug. Pennsylvania-Loan Office

Massachusetts_Loan Office

$7^{\text {th }}$

$31^{\text {st }}$

Sept.

$18^{\text {th }}$

Nov. Pennsylvania-Loan Office $22^{\text {nd }}$

Dec. Pennsylvania-Loan Office
$1,456,417$

$28,323^{*}$

$4,402,413$

New Jersey $\quad 1,456,417$

Pennsylvania $\quad 4,402,413$

$1,139,180$

New Jersey $\quad 1,139,181$

$16,876,618$

Massachusetts $16,876,618$

$2,246,683$

$1,373,811$

$3,817 *$

$221,387^{*}$

Delaware $\quad 2,210,000$

New York 1,373,811

$1,207,111$

New Jersey $\quad 1,207,111$

$3,367,670$

243,127

Pennsylvania $\quad 3,367,670$

$2,805,318$

Pennsylvania $\quad 2,805,318$

$5,009,343$

Pennsylvania $\quad 5,009,343$

$1,599,758$

$38,725^{\mathrm{b}}$

Pennsylvania $\quad 1,599,758$

Massachusetts $\quad 387^{\mathrm{b}}$

New Hampshire 2,900,231 ${ }^{\mathrm{c}}$

$2,954,918$

Pennsylvania $\quad 2,954,918$

$1,000,391$ 


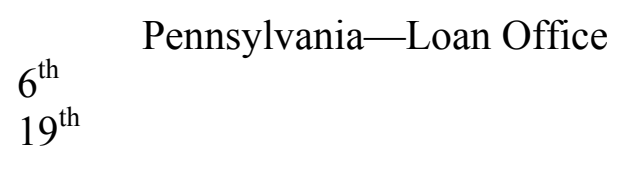

1783

Jan. Pennsylvania-Loan Office

$20^{\text {th }}$
$29^{\text {th }}$

Pennsylvania—Loan Office

Feb. New Jersey-Loan Office

$21^{\text {st }}$

July New Hampshire State Commissioner

1784 None

1785 None

1786

June

$9^{\text {th }}$

July
$2^{\text {nd }}$
$25^{\text {th }}$

Aug.

$2^{\text {nd }}$

$22^{\text {nd }}$

$22^{\text {nd }}$

Sept.

$5^{\text {th }}$

$12^{\text {th }}$

$16^{\text {th }}$

$16^{\text {th }}$

Nov.

$1^{\text {st }}$

$9^{\text {th }}$

Dec.

$7^{\text {th }}$

$13^{\text {th }}$

$29^{\text {th }}$
47,535

331,369

77,623

Pennsylvania $\quad 1,000,391$

Pennsylvania $\quad 77,623$

Pennsylvania $\quad 47,535$

Pennsylvania $\quad 331,369$

392,833

New Jersey $\quad 392,833$

$29,231^{\mathrm{c}}$

None

None

New York $\quad 2,759,217$

New York

848,776

Maryland

827,490

New York

$2,151,478$

Maryland

430,969

Maryland

473,779

Maryland

151,417

Maryland

26,650

132,929

Maryland

$2,880,720$

Virginia

$1,523,224$

Maryland

62,481

Connecticut

$8,102,425$

Maryland

40,072

Maryland

21,750 
July

$5^{\text {th }}$

Virginia $\quad 2,048,160$

Aug.

$13^{\text {th }}$

$17^{\text {th }}$

Rhode Island

$2,593,353$

New Jersey

99,516

Nov.

$13^{\text {th }}$

Pennsylvania $\quad 857,827$

1788

Mar.

$28^{\text {th }}$

New York

172,677

Aug.

$25^{\text {th }}$

Connecticut

$1,049,060$

Sept.

$5^{\text {th }}$

Maryland

$6,780,026$

1789

Mar.

$18^{\text {th }}$

North Carolina $\quad 5,066,861$

Separate Sub-Totals:

$\overline{\$ 111,435,353}^{d}$

$\$ \overline{119,462,370}$

Grand Combined Total (sans overlap):

$\$ 153,526,347$

Continental Dollars Still Outstanding and Unredeemed as of 1790:

If currency emitted for currency swaps and the destruction of said swapped currency are included in the totals- $(241,500,000-153,526,347)=\$ 87,973,653^{\mathrm{e}}$

If only net new emissions (sans currency swaps) and their removal are considered- $\quad(199,990,000-119,462,370)=\$ 80,527,630$

Sources: Derived from Joseph Nourse, Registrar's Office, Board of Treasury, 14 January 1786 report as recorded in the $J C C$ (v. 30, pp. 22-25); and Alexander Hamilton's 11 May 1790 report to Congress (American State Papers, 1832, Class III, Finance, v. 1, pp. 58-59; Elliot, 1843, pp. 
73-76; United States Congress, 1834, v. 2, pp. 1544, 1566) "Schedule E. Statement of the sums, in the old continental emissions, paid by the following States into the treasury of the United States, on account of their several quotas of the requisitions of Congress, of March 18, 1780." Both sources record no payments by Georgia and no payments for the years 1784 and 1785 . Notes:

* Identified by Michael Hillegas, Continental Treasurer, in May of 1782 as being bills of the 20 May 1777 and 11 April 1778 emissions remitted as part of the authorized currency exchange for new bills that occurred between 25 November 1780 and 23 February 1782 (Ferguson, et al., 1980, v. 5, p. 139; Grubb, 2007b, 2008).

${ }^{\mathrm{a}}$ These appear to be the same entry. Which is correct and which is a typo is unclear.

${ }^{b}$ These appear to be the same entry. Which is correct and which is a typo is unclear.

${ }^{\mathrm{c}}$ These might be the same entry, though that is not eminently clear. If they are, which is correct and which is a typo is also not clear. For the purpose of calculating the "Grand Combined Total (sans overlap)" they were counted as independent and separate entries.

${ }^{\mathrm{d}}$ Nourse indicated that his numbers were neither comprehensive nor complete. As such they represent a lower bound of what was actually removed and destroyed in this period.

${ }^{\mathrm{e}}$ Because the number in note $\mathrm{d}$ above is a lower bound, this value is biased high. 


\section{Footnotes}

${ }^{1}$ See Atack and Passell (1994, pp. 71-72); Bezanson (1951, pp. 12, 344); Bolles (1969, v. 1, p. 69); Breck (1843, pp. 15-16); Ferguson (1961, pp. 44, 66); Hughes and Cain (2007, pp. 78830; Phillips (1866, pp. 185, 245-251); Scott (1957, p. 262); Tindall (1988, pp. 226, 263-266, 275-277, 301-307); Walton and Rockoff (2005, pp. 126-127); Webster (1969, p. 502).

${ }^{2}$ See Bolles (1969, v. 1, pp. 194-198); Bronson (1865, pp. 120-138); Bullock (1895, p. 129); Ferguson (1961, pp. 30-35, 53, 64-65); Grubb (2007b); Harlow (1929, p. 67); Holton (2007); Ratchford (1941, pp. 32-33, 37-38).

${ }^{3}$ Ferguson, et al. (1973, v. 1, p. 194); Grubb (2007b); Journals of the Continental Congress [JCC hereafter] (v. 2, pp. 103, 221-222; v. 3, pp. 457-459; v. 4, p. 339; v. 6, p. 1047; v. 14, p. 1013; v. 15, pp. 1019, 1053, 1150, 1171, 1324; v. 19, pp. 164, 411).

${ }^{4}$ Ferguson (1961, pp. 51-52); Grubb (2007b); JCC (v. 16, pp. 263-265; v. 19, pp. 164, 411); Ratchford (1941, pp. 37-38).

${ }^{5}$ A common image offered today is that worthless Continental Dollars were simple smoked in pipes (or used to light smoking pipes). So far, I have not been able to find any reference to said actually from that era. This image may be a latter day myth based on a statement taken from a poem about Maryland paper money in the 1730s (the only reference to using paper money to light smoking pipes that I have found). See Cooke (1730, p. 8).

${ }^{6}$ American State Papers (1832, Class III, Finance, v. 1, pp. 58-59); Elliot (1843, pp. 73-76); United States Congress (1834, v. 2, pp. 1544, 1566).

${ }^{7}$ The only major exception in the cross-corroboration is the May 1781 amount for Virginia $(\$ 5,785,555)$ which is missing from the Hillegas report. As such, the Hillegas report is not listed separately in Table 2 since it is both redundant and incomplete relative to the Nourse report. 
${ }^{8}$ This conclusion is also consistent with the fact that when Nourse (1828) reported what the total emission of Continental Dollars were to the $20^{\text {th }}$ Congress he included the full authorization of January 14, 1779 (\$50 million) in his numbers without netting out bills that were exchanged for the bills of the 20 May 1777 and 11 April 1778 emissions (Grubb, 2007b, 2008).

${ }^{9}$ From July 1780 through 1781 Continental Dollars were being remitted to the U.S. Treasury both as part of the Continental-State currency scheme and as part of the currency swap of the emissions of 20 May 1777 and 11 April 1778 for the emission of 14 January 1779. The evidence does not always distinguish the reason for each specific remittance. By November 1781, however, total remittances across both the Nourse and the Hamilton reports, sans overlap or duplication, were enough to fully account both for the $\$ 41.5$ million currency swap and the $\$ 41.1$ million remitted under the Continental-State currency scheme (Grubb, 2007b, 2008).

${ }^{10}$ See Grubb (2007b); JCC (v. 22, pp. 83-86); and Table 1 above. See also Jefferson's quote below from 25 April 1784, and the discussion of the final reckoning in Ferguson (1961, pp. 205219, 224) and Perkins (1994, pp. 187-196).

${ }^{11}$ See Elliot (1843, p. 12, item \#3). Hamilton estimated the total National Debt (state and national) to be $\$ 77,124,465$ for $1789 / 1790$ (Taylor, 1950, p. 1; Syrett, 1962, v. 6, pp. 85-87). In this number Hamilton included \$2 million Continental Dollars. Thus, Hamilton clearly regarded Continental Dollars to be part of the National Debt. Hamilton also calculated the specie value of Continental Dollars at the default rate of 40 to 1 set by Congress in 18 March 1780$\$ 80,527,630$ million Continental Dollars outstanding in 1790 in face value converts to $\$ 2,013,191$ million in defaulted value. If Hamilton was not simply dividing $\$ 80$ million Continental Dollars by 40 to get $\$ 2$ million Continental Dollars in defaulted value, then his $\$ 2$ million statement is a mysterious curiosity. If he really meant that only $\$ 2$ million Continental 
Dollars in face value were still outstanding at the time, then his proposed default on the Continental Dollar was an unnecessary and reckless act.

12 See Elliot (1843, p. 12, item \#4); Sumner (1968, v. 1, p. 98); United States Congress (1834, v. 2, pp. 2243-2251). Ferguson (1961, p. 67) says in regard to the mass of Continental Dollars issued and outstanding prior to the 1790 default affirmation act, "Eventually the dead mass of currency was drawn in by the states. A good part of it was scattered or destroyed, and in 1790 only about $\$ 6,000,000$ remained in the hands of individuals." Ferguson's source for his $\$ 6$ million number is Elliot (1843, p. 12). As such, Ferguson clearly misinterprets his source here. The $\$ 6$ million was the number estimated to have been actually exchanged at the 100 to 1 default rate for bonds after 1790 , not the amount outstanding at this date, which was estimated to be $\$ 78$ to $\$ 80$ million in the same source. In addition, in reference to 1780 and the withdrawal of old Continental currency, Ferguson (1961, p. 181) also says that the "states absorbed nearly $\$ 120,000,000$.” This is clearly erroneous as it is inconsistent with all other evidence, and no other source shows that much absorbed in 1780 . If by chance Ferguson really meant that the total absorbed by the states between 1780 and 1790 was $\$ 120$ million, then he would be very close to that estimated here in Table 2 and the evidence in his primary source (Elliot, 1843, p. 12, \#3).

${ }^{13}$ Interestingly, while Rhode Island has been universally reviled and tarred with the reputation of being irresponsible with regard to monetary policies and seen as a poster child for badly managed paper money schemes, on this one issue - the remittance of paper Continental Dollars to the national government - it was one of the few responsible states.

${ }^{14}$ See Elliot (1843, p. 12); Grubb (2007a); Newman (1997, p. 69); Sumner (1968, v. 1, p. 980); Taylor (1950, p. 62); United States Congress (1834, v. 2, pp. 2243-2251).

${ }^{15}$ American State Papers (1834, Class IX, Claims, v. 1, p. 55-italics added). 
${ }^{16}$ American State Papers (1834, Class IX, Claims, v. 1, pp. 172-181, 215, 250).

${ }^{17}$ The first statement of depreciation of the Continental Dollar reported in Congress occurred on 11 January 1776, with the next one-a more forceful statement-occurring on 14 January 1777 (JCC, v. 4, p. 49; v. 7, pp. 35-36; Phillips, 1866, pp. 44-46).

${ }^{18}$ See Newman (1997). Exceptions include Maryland's paper pound from 1767-1774 which stated that it was redeemable in "bills of exchange payable in London, or Gold and Silver, at the rate of four shilling 6 pence sterling per dollar..." Maryland had purchased with prior tax revenue stock in the Bank of England and used the liquidation of said stock to redeem its money in London at the stated rate. New Hampshire, New Jersey, and Rhode Island were at times also exceptions. See Newman (1997, pp. 167-169, 225-235, 246-254, 378-389).

${ }^{19}$ American State Papers (1834, Class IX, Claims, v. 1, p. 215).

${ }^{20} J C C$ (v. 4, pp. 49, 339-340, 382; v. 5, p. 724).

${ }^{21}$ See Archives of Maryland (v. 43, pp. 258-259); Bolles (1969, v. 1, pp. 97-98, 135-136); Boyd (1953, v. 7, pp. 221-223); Bullock (1895, pp. 136-138; 1900, p. 72); Elliot (1843, pp. 7782); Ferguson (1975, v. 2, pp. 70-71); JCC (v. 16, p. 265; v. 23, pp. 560-561, 590); Phillips (1866, pp. 160-166); Sumner (1968, v. 1, pp. 87-89); Webster (1969, p. 111).

${ }^{22}$ See Carp (1984, pp. 68-73, 90, 97, 186); Ferguson (1961, pp. 39-40); Figure 3 above; JCC (v. 15, pp. 1334-1336; v. 16, pp. 343-345; v. 17, pp. 566-569).

${ }^{23}$ See $J C C$ (v. 17, pp. 784-785; v. 19, p. 266; v. 26, pp. 395-396; v. 27, pp. 540-545).

Jefferson's table of depreciation did not exceed 40 to 1 until after November of 1779, see Boyd (1954, v. 10, p. 43) and Figure 3 above.

${ }^{24}$ See Bezanson (1951, pp. 12, 344); Breck (1843, p. 16); Ferguson (1961, p. 66); Webster (1969, p. 502). 
${ }^{25}$ For the case of Delaware which explicitly passed laws to stop the acceptance of Continental Dollars by state officials after its quota was filled, see Grubb (2007b).

${ }^{26}$ In many cases states would accept Continental Dollars in payment of their taxes only at rates far above the 40 to 1 in specie set by Congress on 18 March 1780, such as at 75 to 1 set by Pennsylvania (Bronson, 1865, pp. 128-136; Phillips, 1866, pp. 182-184; Sumner, 1968, v. 1, p. 95; Webster, 1969, pp. 171, 501-502).

${ }^{27}$ See also Boyd (1954, v. 10, pp. 17, 26; 1955, v. 12, p. 61).

${ }^{28}$ See Ferguson (1961, pp. 273-284, 297-302); Holton (2007, pp. 256-261); Perkins (1994, pp. 221-231); Taylor (1950, pp. 19-40).

${ }^{29}$ The subtleties are a little more complex than portrayed, but that complexity is not relevant to the story here. See Garber (1991). 